\title{
Comparative Study of Conventional Electrocautery Versus Ultrasonic Dissector in Laparoscopic Cholecystectomy
}

\author{
Saad Bin Anis 1, Pir Muneeb Rehman 2, Farhan Ahmad ${ }^{3}$, Umar Farooq 4 \\ ${ }^{1}$ Resident, Department of Neurosurgery, Agha Khan University Hospital, Karachi \\ ${ }^{2}$ Consultant, Department of surgery, Life Care Hospital, Bahria Town, Lahore \\ ${ }^{3}$ Resident, Department of General Surgery, Jinnah Hospital, Lahore \\ ${ }^{4}$ Resident, Department of Surgery Jinnah Hospital, Lahore
}

\section{ABSTRACT}

\begin{abstract}
Background: Laparoscopic cholecystectomy (LC) is very commonly performed for removal of gallstones. In routine, ultrasonic devices are used for laparoscopy involving the deeper operating fields, while electrosurgical devices are preferred for LC. However, nowadays both of these devices are used for LC. The objective of this study was to compare the surgical outcomes of ultrasonic dissector over conventional electrocautery in patients planned for LC.

Material and Methods: This non-randomized clinical trial was conducted in general surgery unit, Jinnah hospital Lahore. The study duration was $15^{\text {th }}$ January 2015 to $31^{\text {st }}$ December 2016. In group A ( $\left.n=100\right)$, patients were operated through three-port standard laparoscopic cholecystectomy and conventional electrosurgical cautery was used for dissection. While in group $B(n=50)$, patients were operated through single incision laparoscopic surgery (SILS) and Harmonic dissector was used for sealing of cystic artery and cystic duct. SPSS version 23 was used for data analysis. Complications between electrocautery and ultrasonic dissector were compared using chi-square test/Fischer exact test and operative time was compared using student's t-test with $p$-value $\leq 0.05$ considered as statistically significant.
\end{abstract}

Results: Out of 150 patients planned for laparoscopic cholecystectomy, $33(22 \%)$ were males and $117(78 \%)$ females. The mean age was $40 \pm 6.45$ years with an age range of $12-80$ years. In group $A$, intraoperative gall bladder perforation was found in 5 patients whereas in group $B$, there was only one patient with perforation. $A$ total of 4 cases were converted to open cholecystectomy in group A due to difficult dissection in Calot's triangle as compared to 1 case in group B. In group A, 3 cases had postoperative bile leakage in the drain. In two patients it settled over a period of 3 days. About 03 cases had wound infection in group $A$ and 1 in group $B$. Mean operative time in group $A$ was $42.2 \pm 8.93$ minutes versus $35.7 \pm 4.85$ minutes in group $B$ ( $p$-value 0.001 ).

Conclusion: In this study, the rate of post-operative complications was similar between the two groups, but operative time was significantly shorter in the group B. Harmonic dissector enabled easy dissection of tissues with good hemostasis and less trafficking of instrument, avoiding use of clips and sutures during minimal invasive surgery.

Key words: Electrocautery, Laparoscopic cholecystectomy, Ultrasonic dissector

\begin{tabular}{|c|c|c|}
\hline $\begin{array}{l}\text { Authors' Contribution: } \\
1,2 \text { Conception, synthesis, planning of } \\
\text { research and manuscript writing }{ }^{3} \\
\text { Interpretation, discussion, Active } \\
\text { participation in data collection } \\
{ }^{4} \text { Data analysis. }\end{array}$ & $\begin{array}{l}\text { Correspondence: } \\
\text { Pir Muneeb Rehman } \\
\text { Email: dr_pm@outlook.com }\end{array}$ & $\begin{array}{l}\text { Article info: } \\
\text { Received: January 8, } 2019 \\
\text { Accepted: April 19, } 2019\end{array}$ \\
\hline \multicolumn{2}{|c|}{$\begin{array}{l}\text { Cite this article. Anis S, Rehman PM, Ahmad F, Farooq U. Comparative Study of Conventional } \\
\text { Electrocautery Verses Ultrasonic Dissector in Laparoscopic Cholecystectomy. J Islamabad } \\
\text { Med Dental Coll.2019; 8(2):70-73 }\end{array}$} & $\begin{array}{l}\text { Funding Source: Nil } \\
\text { Conflict of Interest: Nil }\end{array}$ \\
\hline \multicolumn{3}{|c|}{ Introduction } \\
\hline $\begin{array}{l}\text { Laparoscopic cholecystectomy (L } \\
\text { performed for removal of galls } \\
\text { electrosurgical energy dissectors }\end{array}$ & \multicolumn{2}{|c|}{$\begin{array}{l}\text { dissection devices during LC. }{ }^{2} \text { These high energy devices } \\
\text { are used during surgical procedures to reduce blood loss } \\
\text { intraoperatively and at the same time used to cut, }\end{array}$} \\
\hline
\end{tabular}


coagulate, desiccate or fulgurate the tissues. The conventional electrocautery uses electrical current for achieving these goals during surgery either open or laparoscopic. It is of two types, in unipolar the current goes through the patient to complete the current cycle and in bipolar cautery, the current flows through tissues between the electrodes of the instrument. ${ }^{3}$ However, its use during LC can cause damage to the adjacent organs such as common bile duct, stomach or intestines. It can also cause liver injury, loss of bile or gallbladder perforation. ${ }^{4}$ Ultrasonic (harmonic) scalpel was developed to resolve this issue. ${ }^{5}$

Harmonic Dissector (HD) was introduced in 1992 by Ethicon Endo surgery USA, and surgeons have used this instrument in more than 14 million procedures worldwide. With this instrument ultrasonic vibrations are generated at the probe which generates friction. It produces vibrations in the range of 20,000 to $50,000 \mathrm{~Hz}$ and this friction leads to denaturation of proteins, which leads to coagulation and as heat goes up to $200^{\circ} \mathrm{C}$, tissue is transected with minimal collateral damage. ${ }^{6}$

Ultrasonic dissectors are new addition in the instruments for laparoscopic procedures, and perform dissection and ligation of vessels by coaptation and cavitation. ${ }^{7}$ In routine, ultrasonic devices are used for laparoscopy involving the deeper operating fields, while electrosurgical devices are preferred for LC. ${ }^{8}$ However, nowadays ultrasonic dissectors have also started being used during routine LC procedures. ${ }^{9,10}$ The present study was designed to compare the surgical outcomes of ultrasonic dissector with conventional electrocautery dissection used for laparoscopic cholecystectomy

\section{Material and Methods}

This non-randomized clinical trial was conducted at General Surgery unit Jinnah hospital Lahore from $15^{\text {th }}$ January 2015 to $31^{\text {st }}$ December 2016. Out of total 150 patients that were planned to undergo LC, 130 were admitted through OPD and 20 patients through emergency. This study was approved by Ethical Review Committee of Jinnah hospital, Lahore. Patients fit for general anesthesia and willing for laparoscopic cholecystectomy were included, while patients with pre- existing cardio respiratory comorbid factors, having more than one previous abdominal surgical scars, presenting after four days of acute cholecystitis or having choledocholithiasis along with gall stones were excluded from the study.

After taking written informed consent, the principal investigator divided the patients into two groups. In group A $(n=100)$, patients underwent standard three-port approach and conventional electrosurgical cautery was used for dissection. While in group $B(n=50)$, patients were operated through single incision laparoscopic surgery (SILS) and HD was used for sealing of cystic artery and cystic duct.

After giving preoperative antibiotic, cephalosporin (1 Gm) and general anesthesia, patients were prepared. Pneumoperitoneum was created using $\mathrm{CO}_{2}$ in all patients through Veress needle. SILS was done by giving a supraumbilical incision (ranging from $1.5-2.5 \mathrm{~cm}$ ). Drains were placed in few cases of electrocautery group and no drain in Harmonic dissector group. After LC, Patients were kept in ward for 24-48 hrs. Antibiotics, I/ $\mathrm{N}$ fluids and analgesia was given according to the status of the patients. Surgical outcomes were measured in terms of total procedural time and frequency of post-operative complications such as gall bladder perforation, conversion to open cholecystectomy, postoperative bile leak and wound infection.

SPSS version 23 was used for data analysis. Complications between electrocautery and ultrasonic dissector were compared using chi-square test/Fischer exact test and operative time was compared using student's t-test with $p$-value $\leq 0.05$ considered as statistically significant.

\section{Results}

Out of 150 patients planned for laparoscopic cholecystectomy, there were $33(22 \%)$ males and 117 $(78 \%)$ females. Age range of patients was $12-80$ years with a mean age of $40 \pm 6.45$ years. Intraoperative gall bladder perforation and wound infection was more in group $A$ and more cases were converted to open cholecystectomy due to difficult dissection in Calot's 
triangle. In group $B$, only 1 incision was extended as anatomy was not clear in Calot's triangle. In group $A$, out of 3 cases that had postoperative bile leakage in the drain, two patients settled down over a period of 3 days. Endoscopic Retrograde Cholangio-Pancreatography (ERCP) was performed in one patient and accidental stone was found in common bile duct (CBD) which was retrieved by papillotomy. Range of operative time in group $A$ and $B$ was $35-70$ minutes and 33-40 minutes. Mean operative time in group A was more as compared to group B (Table I)

\begin{tabular}{|l|c|c|c|}
\hline \multicolumn{4}{|c|}{$\begin{array}{c}\text { Table I. Comparison of factors assessing surgical outcomes } \\
\text { in patients undergoing laproscopic cholecystectomy }\end{array}$} \\
\hline \multicolumn{1}{|c|}{ Variables } & $\begin{array}{c}\text { Group A } \\
(\mathbf{n = 1 0 0 )} \\
\mathbf{n}(\%)\end{array}$ & $\begin{array}{c}\text { Group B } \\
(\mathbf{n}=50) \\
\mathbf{n}(\%)\end{array}$ & $\mathbf{p}$-value \\
\hline $\begin{array}{l}\text { Operative Time (mins) } \\
\text { mean } \pm \text { SD }\end{array}$ & $42.2 \pm 8.9$ & $35.7 \pm 4.9$ & 0.0001 \\
\hline Gall Bladder perforation & $5(5)$ & $1(2)$ & 0.37 \\
\hline $\begin{array}{l}\text { Conversion to Open } \\
\text { Procedure }\end{array}$ & $4(4)$ & $1(2)$ & 0.52 \\
\hline Post-op Bile Leakage & $3(3)$ & $0(0.0)$ & 0.55 \\
\hline Wound Infection & $3(3)$ & $1(2)$ & 0.72 \\
\hline
\end{tabular}

\section{Discussion}

In gallbladder surgery, a decrease in operative blood loss, less local thermal damage to tissue, less gallbladder perforation and common bile duct injury, less intraoperative time and more cost effectiveness are the aims. This can be achieved when the equipment, technique, and experience reach the optimum level of requirement. ${ }^{11}$

We found that HD is multi-functional in performance as it is used for dissection, sealing of vessels and cystic duct and it obviates the exchange of instruments such as $L$ hook. There is no smoke produced during its use which is inherent with electrocautery use. There is only snow falling effect which does not hinder the vision over the monitor and decreased the operative time. There is good securing of hemostasis during dissection and little need of irrigation. On the other hand, in electrocautery group there are problems during dissection, difficulty in securing hemostasis and because of smoke release vision was blurred. All these lead to an increase in the operative time, increased incidence of complications such as gall bladder perforation, postoperative drain placement, postoperative bile leakage and wound infection. These factors also lead to increased dose of analgesia in postoperative period in the EC group.

A study by Jain et al showed that use of HD during LC is associated with shorter procedural time, taking less time to remove gallbladder from its bed, low pain score and less blood loss. Also, they reported shorter hospital stay with the use of HD but they did not report any incidence of major complications or bile leak during a 6 -month followup period in either of the groups. ${ }^{6}$

Another study from Egypt reported operative time of $33.21+9.6$ minutes in $\mathrm{HD}$ group as compared to $51.7 \pm 13.8$ minutes in EC group. The authors also reported lower rate of conversion in $\mathrm{HD}$ group and no risk of bile leakage and very small amount of blood loss. These authors further concluded that HD provides complete hemobiliary stasis and is a safe alternative to standard clipping of cystic duct and artery. It provides a shorter operative duration, less incidence of gallbladder perforation, less postoperative pain, and less rate of conversion to open cholecystectomy. ${ }^{11}$ Sanawan et al. found that blood loss and procedural time is reduced using $\mathrm{HD}$ during $L C .{ }^{10}$

Ramzanali at al. also reported that multiple functions can be safely performed using harmonic scalpel such as cavitation, coaptation and cutting and is safer and reliable when compared with conventional electrocautery dissector. ${ }^{10}$ Shabbir et al. and Ali et al. found significantly higher gallbladder perforation rate using electrocautery when compared to harmonic scalpel during LC. ${ }^{12,13}$

Outcome of our study in terms of operative time, gallbladder perforation, postoperative bile leakage, preoperative hemobilliary stasis, conversion to open cholecystectomy correlates with the above-mentioned studies.

\section{Conclusion}

In this study, the rate of post-operative complications was similar between the two groups but operative time was significantly shorter in the group $B$ in comparison with the 
conventional method. During surgery, it was observed that HD makes dissection of tissues easy with good securing of hemostasis, less trafficking of instruments and less use of clips and sutures. There were also minimal chances of injury to adjacent structures as compared to EC group.

\section{References}

1. Agresta F, Campanile FC, Vettoretto N, Silecchia G, Bergamini C, Maida $\mathrm{P}$, et al. Laparoscopic cholecystectomy: consensus conference-based guidelines. Langenbeck's Arch Surg. 2015; 400(4): 429-53. doi: 10.1007/s00423-015-1300-4

2. Alkatout I, Schollmeyer T, Hawaldar NA, Sharma N, Mettler $\mathrm{L}$. Principles and safety measures of electrosurgery in laparoscopy. J Soc Laparoendosc Surg. 2012; 16(1): 130. doi: 10.4293/108680812X13291597716348

3. Lee C-L, Huang K-G, Wang C-J, Lee P-S, Hwang L-L. Laparoscopic radical hysterectomy using pulsed bipolar system: comparison with conventional bipolar electrosurgery. Gynecol Oncol. 2007; 105(3): 620-4. doi: 10.1016/j.ygyno.2007.01.029

4. Wolfe BM, Gardiner B, Frey CF. Laparoscopic cholecystectomy: a remarkable development. J Am Med Assoc. 2015; 314(13): 1406. doi:10.1001/jama.2014.12014

5. Williams N, O'Connell PR. Bailey \& Love's Short Practice of Surgery 26th ed: Crc Press; 2013.

6. Jain SK, Tanwar R, Kaza RCM, Agarwal PN. A prospective, randomized study of comparison of clipless cholecystectomy with conventional laparoscopic cholecystectomy. J Laparoendosc Adv Surg Tech. 2011; 21(3): 203-8. doi: 10.1089/lap.2010.0455
7. Devassy R, Hanif S, Krentel H, Verhoeven HC, Torres-de la Roche LA, De Wilde RL. Laparoscopic ultrasonic dissectors: technology update by a review of literature. Med Devices (Auckl). 2019; 12:1. doi: 10.2147/MDER.S113262

8. Park AE, Mastrangelo Jr MJ, Gandsas A, Chu U, Quick NE, editors. Laparoscopic dissecting instruments. Semin Laparosc Surg. 2001; 8(1): 42-52 PMID: 11337736

9. Sanawan E, Qureshi AU, Qureshi SS, Cheema KM, Cheema MA. Effectiveness of Ultrasound Shear for Clipless Laparoscopic Cholecystectomy Versus Conventional Unipolar Electrocautery in Patients with Cholelithiasis. J Coll Phys Surg Pak. 2017; 27(10) :00. doi: 2719.

10. Ramzanali SA, Shah SSH. Monopolar electrocautery versus ultrasonic dissection of the gallbladder from the gallbladder bed in laparoscopic cholecystectomy. J Ayub Med Coll Abbottabad. 2013; 25(3-4): 16-8. PMID: 25226730

11. Kandil T, El Nakeeb A, El Hefnawy E. Comparative study between clipless laparoscopic cholecystectomy by harmonic scalpel versus conventional method: a prospective randomized study. J Gastrointest Surg. 2010; 14(2): 323-8. doi: 10.1007/s11605-009-1039-8

12. Shabbir A, Hussain S. Comparison of Gallbladder Perforation During Dissection from Liver Bed in Patients Undergoing Monopolar Electrocautery with Those Undergoing Ultrasonic Dissection during Lap. Cholecystectomy. Pak J Med Health Sci. 2016; 10(4): 1390 2.

13. Ali M, Akbar A, Khan MUR, Ullah MH. Comparison of incidence of gallbladder perforation in laparoscopic cholecystectomy with harmonic scalpel vs electrocautery. Pak J Med Health Sci. 2015; 9(2): 511-3. 